Article

\title{
New Interpretations from Sustainable Economy
}

\author{
Elham Ataei ${ }^{1}$, Nima Norouzi ${ }^{2, *(D)}$ \\ ${ }^{1}$ Department of Political Science, Political science Faculty, Payam Noor University, Tehran, Iran \\ ${ }^{2}$ Energy engineering and physics department, Amirkabir university of technology (Tehran Polytechnic), Teh- \\ ran, Iran \\ *Correspondence: n.nima1376@gmail.com;
}

How to cite this paper: Ataei, E., \& Norouzi, N. (2021). New interpretations from Sustainable Economy.

Universal Journal of Finance and Economics, 1(1), 13-30. Retrieved from https://www.scipublications.com/journal/index.php/ujfe/article/view/107

Received: August 18, 2021 Accepted: September 22, 2021 Published: September 23, 2021

Copyright: (C) 2021 by the authors. Submitted for possible open access publication under the terms and conditions of the Creative Commons Attribution (CC BY) license (http://creativecommons.org/licenses /by/4.0/).

\begin{abstract}
The present work abounds in lathe comments on the ecological, economic policy. The first refers to the layers of thermodynamics and the economic process, but does not describe the importation of analyzing the dynamics of the economic process in terms of the transfer of matter and energy, and it is a natural system. Secondly, it is a revision of the main plant-like portraits by Marx and Engels with the historical background that plays naturalness in the process of social reproduction. The third radical commentary on reflecting the theory of value, considering that the system can count with a theory of value based on quantities of energy, is limited. The reason is sensible: as long as the capital is valued at no cost from the exploration of the work, it is natural without embargo as a limitation. And as in the last comment, we only see the political economy from a green perspective. Green in the sense that to perform economic analysis, even historical ones, it is necessary to include the natural resource variable and keep the manager accountable with critical info.
\end{abstract}

Keywords: Ecological economics; Economic process; Value theory; Sustainable Economics

\section{Introduction}

During the last three decades, nature has become a variable of fundamental importance in studying the process of economic reproduction on a global scale. Its incorporation into the socioeconomic analysis is not a sine qua non condition, but it is fundamental in understanding the functioning of contemporary capitalism, which exploits the labor force and natural resources[1]. And this is so because work and land make up the material basis of social reproduction. The pressure exerted by the rate of profit has led to resort not only to generating new methods of extracting surplus labor but also to old procedures of appropriation and exploitation of the means of subsistence. The international division of labor shows an example of natural resources, which has manifested itself in their depletion and erosion on a planetary scale. With this, the planetary ecosystem has been disrupted, causing climate change due to the increasing consumption of fossil hydrocarbons[2]. ${ }^{1}$

To study contemporary capitalism, at least from one of its multiple edges, the set of natural resources is considered a determining and neuralgic element in the conduct of the economic system on a world scale. For this reason, topics such as ecological economics must be increasingly discussed within the programs of various university degrees. And not only there, but transcending the educational institutional borders capable of impregnating society with a different form of social organization, not to perpetuate capitalism

1 The main changes are manifested in the thawing of large masses of polar ice; in the carbon, sulfur, hydrogen, hydrological cycles, among others; increase in the temperature level of the oceans; modifications in rainfall patterns. For more details on climate change see WMO-UNEP (2007). 
and the consequent division of classes, rather generate alternative forms of the harmonious social organization of man with man and man with nature[3].

Based on the above, it is necessary to continue with critical heterodox thinking that highlights nature. This essay offers a synthesis of what the author considers to be the main elements of the political-ecological economy, based on four comments[4] - the first studies the socioeconomic system as an open system in terms of matter and energy. Thus, allnatural resource users in production processes have an irreversible effect on the ecosystem[5]. The second comment argues that Marx and Engels did not ignore the dialectical relationship between man and nature, since in the first volume of the capital such, "The work process and the valorization process," the transhistorical law of the production process is exposed, where man has taken from nature the necessary resources for its reproduction. In addition, in "The role of work in the transformation of the monkey into man," a constituent fragment of the dialectic of nature, the importance of work in the development of human civilization is traced[6-10]. ${ }^{2}$

The following two comments are developed based on heterodox and critical economic theory: one is valued, and the other is praxis. The third comment focuses on the objective theory of value, from the conception of value based on the amount of energy incorporated in the production of goods. It is not a question of eliminating the labor theory of value, but rather of rethinking the possibility of incorporating an energy transfer approach in the value of goods, bearing in mind the social relations of production and the man-land relationship. And finally, the fourth comment focuses on the red-green perspective of political economy. In this way, environmental thinking needs to be self-critical since setting aside a concomitant vision of the global and the local[11].

\section{The economic process and the laws of thermodynamics}

The dominant economic theory (neoclassical) is characterized by being "ahistorical," "mechanical," and "reversible." It lacks historical specificity since it does not identify its starting point and results in a slave, feudalism, or capitalist society. It is not organic in terms of the relationship between its component elements, since the effect caused by one element on another is unique, unidirectional, and without return. And it downplays future events derived from present actions[12].

The high theoretical-methodological risk is run by assuming the global economic process as a system without historical context and linearly mechanically reversing social phenomena over time. In addition, and in a broader sense, the risk appears with the above and when an excessively optimistic position is assumed when observing a completely closed economic and social system in terms of flows of matter and energy, therefore selfsustaining[13]. Generally, the economic system is studied as a closed system in the sense of not considering it as a whole, only as a limited set of determining elements with fixed relationships and, above all, previously assumed. This leads us to the results of mechanical processes since when taking into account only fractions of the whole; the system is lost sight of; however, the most dangerous thing is to obtain a system that reproduces itself perennially. Neoclassical economic theory offers us a circular diagram between production and consumption, where nature (natural resources) does not influence the economic process. For its part, the Marxist approach provides an analytical structure of the capitalist

2 In general, we can argue that the socioeconomic system is studied from two approaches: one is associated with the conventional tradition of the mainstream, and considers the system's phenomena as ahistorical and reversible; the other, which we can well associate with heterodoxy, gives a high preponderance to historical events such as social, economic, political formation processes, etc., which have their impact throughout society in temporal and territorial terms. 
reproduction process, also without including the environment as an active agent of the economic system. Faced with this situation, we must bear in mind that "(..) all economic history indisputably proves that nature plays a preponderant role in the economic process and in the formation of economic value" [14-18](see Figure 1). ${ }^{3}$

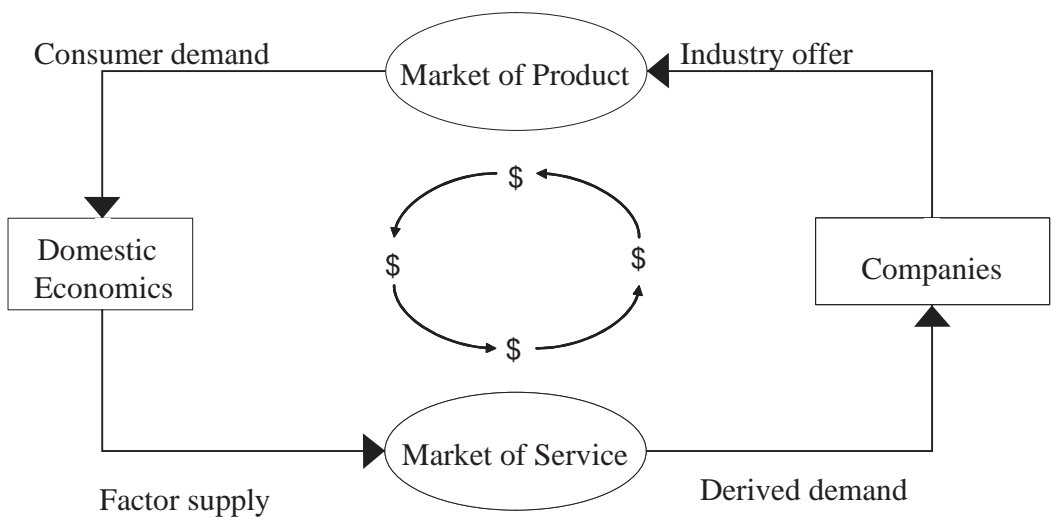

Figure 1. Circular flow of the economy

In graphic terms, we have two representations of the circular flow of the economic system. The first indicates the conventional perspective, while the second is the Marxist approach; no consequence of using natural resources can be inferred from both schemes. Figure 1 shows the physical flow and monetary ebb of an economic system from the conventional approach. On the one hand, as a flow, we have the sale of the so-called factors of production in their respective market for the production of goods and services, which will later be sold to families and companies; on the other hand, like an ebb, the purchase shows the payment of said transactions that is manifested in the income of the producers and the wages of the families[19-23].

We get this scheme's result is a closed economic system, and we don't know what happens to the flow of matter and energy. However, its contribution is to identify the transformation process: on the one hand, raw materials come in; on the other, goods come out either to consume or produce other goods. Apparently, under this analysis, everything is in order, but in reality, in terms of material and energy resources, knowing the result of the said process of transformation of the raw material is unknown. We also have to answer another question: what happens when the consumption process takes place? In studying the economic process within the conventional approach to economics, these concerns are not found, much less the answers[24].

Also, in the Marxist approach, the economic process is a closed system in terms of the transfer of matter and energy. Let us take as a starting point the social relations of production, which are of the salaried type, which implies private ownership of the means of production. The workers, being dispossessed of the means of production, have nothing to sell but only their physiological capacities, their labor power. In this exchange process, the workers receive a salary, a monetary flow, but in exchange, they give up their physical powers for a certain time to be exploited by the former. What has been affected is nothing

3 As will be presented in the next section, Marx raises the relationship that man has had with nature throughout the development of human civilization. Based on this norm, the transhistoric law of production, economic activity has subordinated the development process to nature. A fundamental characteristic of production is not only the exploitation of labor, but also of natural resources. 
but an ebb and flow of things; On the one hand, a monetary flow is a payment for wages. On the other, there is a real flow that is the disposition of the workforce by the capitalist[25-30].

Figure 2 offers a representation of the intersectoral economic flows that take place in the capitalist reproduction process. ${ }^{4}$ Based on the reproduction schemes (simple and extended), considering two sectors (producers of means of production of consumer goods, respectively), in global economic activity as well as two social classes (workers and capitalists), we have a set of flows in real and nominal terms. Still, regardless of the relationship with nature, it does not incorporate the material and energy flow from the potentialities of nature, and neither does their reflux as waste(see Figure 2).

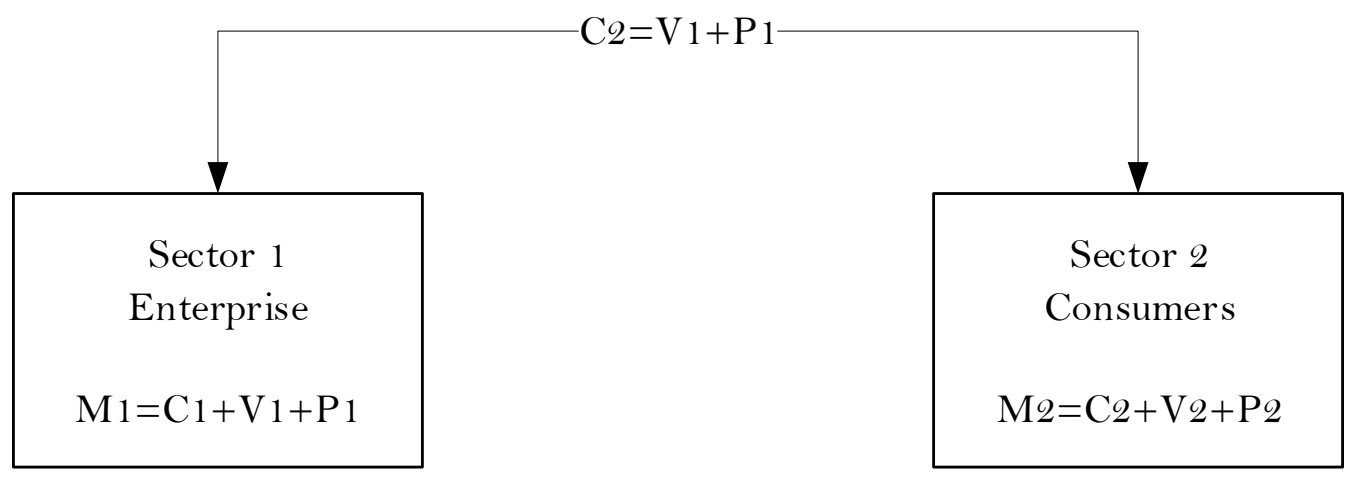

Figure 2. Economic flows in the process of simple capitalist reproduction

To study the economic process integrally, it is necessary to consider it as a whole, but as long as it is examined exclusively from the physical point of view. We must consider the movement of matter and energy, which is described in the laws of thermodynamics. With this, it is possible to determine the extent to which the closed system is determined by external factors and the complete dependence of material production on nature. The first of these laws is energy conservation, which states that all matter and energy are neither created nor destroyed, only transformed. The energy existing in a system does not vary in its quantity but only in its form. The second is the law of entropy, which poses an inaccessible energy measure of a closed thermodynamic system. ${ }^{5}$ In other words, entropy is a measure of the energy not available within a closed system, such as the economic one, which is related to the system's state, and that said measure varies according to the increase in heat considered [31]. And by available (or free) energy is understood that over which man could exercise almost complete control, while unavailable energy is that which can never be used. ${ }^{6}$

In this sense, the closed system, also called the economic subsystem, is part of the global ecological system and depends directly on the energy flow available in it (see Figure 3). This subsystem does not produce energy; it only transforms it, since it continuously absorbs and repels it; the difference is not merely quantitative, because what goes in "always" is equal to what goes out, but qualitative because it is characterized by the disorder

${ }^{4} \mathrm{M}, \mathrm{C}, \mathrm{V}$ and P represent the market value, constant capital, variable capital and the mass of surplus value, respectively for the sector in question.

${ }^{5}$ It can be said that entropy is a measure of the disorder of the available energy.

${ }^{6}$ For example, the chemical energy contained in a barrel of oil is free energy, since man is capable of transforming it into heat energy and therefore into mechanical work, however in this process the energy dissipates, so man already you will not be able to use it. Keep in mind that the amount of energy did not undergo any variation. 
of matter and energy[32]. The energy that leaves the economic process is of a higher level of entropy concerning the one that has entered. Exergy reaches the closed system, a certain level of available matter and energy of low entropic level, for which the outgoing energy is disordered and dissipated[33]. As a fundamental part of the economic system, the production process uses natural raw materials to produce goods. The result of this process is adverse for the matter and available energy because when using it, for example, when burning hydrocarbons as fuel, in the short term, it cannot be ordered if it is not through a long-term process by which the ecosystem is rearranged. ${ }^{7}$

While it is true that the economic process produces means of subsistence for the human species, it is also true that this achieves it at the cost of dissipating energy and degrading environmental conditions, of unbalancing the ecosystem. The generation of a higher entropic level brings pollution and waste to nature, from where it is difficult for a man to regain the energy represented by the materials taken from it. By incorporating the flow of matter and energy, we will have a more comprehensive approach. In the circular flow of the economy, for example, the chemical energy contained in a barrel of oil is free, since man is capable of transforming it into heat energy and therefore into mechanical work, however in this process, the energy is dissipated, so man you will no longer be able to use it[34]. Keep in mind that the amount of energy did not undergo any variation.

It will no longer be closed, mechanical, or self-sustaining; ${ }^{8}$ on the contrary, we have a perspective where the reproduction of the socioeconomic system depends on the material conditions given by nature. This brings us to a crucial issue: irreversibility. Given the conditions of degradation of matter-energy, it is impossible to return it to its initial state only through increased entropy elsewhere. ${ }^{9}$ When dissipating a certain amount of energy that needs to be returned to its previous state, a For example: “(...) when the heat of a closed system has spread in such a way that the temperature has become uniform throughout the system, the movement of heat cannot be reversed without external intervention" [36]. Reducing the heat in a room is done through air conditioning, which requires electrical energy to generate fuel.

7 “(...) the economic process receives valuable natural resources and releases worthless waste".

8 Let's have a closed system, for example a room with an electric stove and a bucket of freshly boiled water. The entropy law tells us that the heat from the boiled water will be continuously dispersed throughout the system, so a thermodynamic equilibrium will be reached, that is, a state where the temperature is uniform throughout the system and all the energy is unavailable. We can make the water in the bucket hot again, but it will be at the cost of dissipating another amount of energy, therefore increasing the entropy.

9 "It is a thermodynamic quantity that indicates the maximum theoretical work that can be achieved by the spontaneous integration between the closed system and the envi-ronment. It informs about the usefulness of the system as a source of work ". 


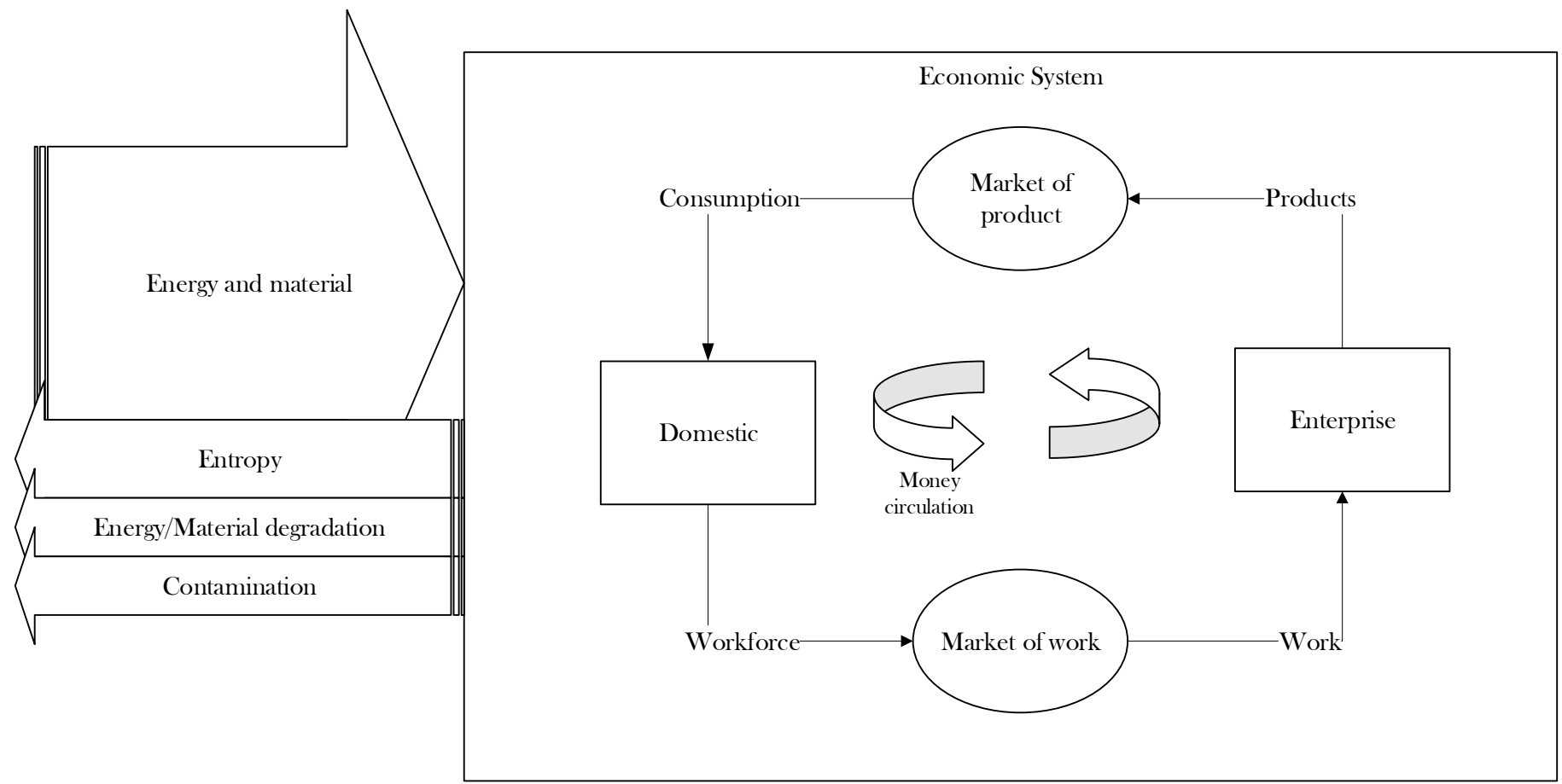

Figure 3. The global ecological system. The economy in the ecological vision

The analytical schemes to study the economic system place the productive process transforming useful natural resources (low entropy) into waste (high entropy), but ultimately justified. It is rational for man to take food from nature and the means to satisfy his needs[37]. Any other non-human animal performs the same procedure, so the entropy acquires a natural character. The increase in the level of entropy due to its social character is what disorganizes energy irrationally. So we can ask ourselves the question: why should this process continue? From the analysis that considers the flow of matter-energy, the teaching is derived that man's economic struggle is continually located in the low entropy of the environment, which is found in limited quantities[38].10

Consequently, nothing could be further from the truth than affirming that the economic process is an isolated and circular question, as represented by traditional and Marxist analyses. The economic process is solidly founded on a material base subject to certain restrictions. Due to these obstacles, the economic process has an irrevocable one-way evolution. Considering the latter, it would seem that economists of both tendencies have succumbed to the worst economic fetishism: monetarism [39].

For this fundamental reason, it is necessary to call on the different generations of humanity to contemplate in their lifestyles that natural potentialities are finite and irreproducible with man's work. One of the prominent studies is that of the bearing capacity of the earth, according to Pfaudler[40].

Pfaudler's article can be placed intellectually not only in the social-Darwinian context but also among the ecological critiques of economic theory, since it does not use the usual analytical tools of economists, such as the notion of "diminishing returns," but rather focuses the economy from the ecological point of view "[41, 42].

10 Under the Marxist analysis scheme, we have that Marx himself (1885) did not include the flow of matter-energy in the global reproduction process in the reproduction schemes. See also, once again, figure 2, where although the inter and intra-sector exchange process is described, it does not consider the relationship that the economic reproduction process has with natural reproduction. 
In this sense, the question is: what is the calculation of the maximum population that can live within a certain territory? For Pfaundler, the bearing capacity of the earth is between two limits. On the one hand, as the aggregate of the individual support capacities of the territories according to their availability of materials, and on the other, attending to the free mobility of materials[43].

\section{Nature in economic activity: the contributions of Marx and Engels}

Starting from these authors' approaches to studying the historical development of society, whether in its abstract or specific figure such as the capitalist, we have that individuals enter into social relations regardless of their will. These social relations correspond to a certain level of development of the productive forces, but they also represent the antagonism between social classes. The improvements that work instruments have historically had are the result of work itself, modifying the ways of producing, and especially the way of organizing the production process. All these material characteristics constitute the economic structure. But society is also made up of relations of a political nature, where the set of formal and informal institutions rest, for example, the legal, political and social of a non-productive nature. This set of non-material relationships is a reflection of the relationships that individuals develop within the economic structure. The social space where these types of relationships develop and manifest is named superstructure [44]. Now, locating ourselves only in the space of the economic structure, historically, individuals need to control nature to procure their means of subsistence. Regardless of the mode of production where we are located, these social relations are of production, so it is a general law of a transhistorical nature[45].

It is true that nowhere in the works written by Marx or Engels is there a systematization of the role of nature in the global process of capitalist reproduction. This document emphasizes the interest of presenting a comment referring to identifying "relatively" isolated ideas that offer the basis for analyzing natural resources in the capitalist mode of production. In the first instance, what we have is the work process [46], where the relationship between man and nature is traced; The first takes from it the elements necessary to satisfy his needs, that is, he appropriates the potentialities of the earth and places them as an object of work, which will take the form of raw material after passing a certain production process. The workforce transforms this work object through the working medium to obtain a use-value. The conjunction of force and work environment on the object is the work process that Marx defines as "(...) the activity of man, through the work environment, modifies the work object sought beforehand" in addition to the fact that "(...) it is an activity-oriented to an end, that of the production of use-values, appropriation of usevalues, appropriation of the natural for human needs, general condition of the metabolism between man and nature" [47]. Therefore, the labor process implies the imperative need to control nature by man, but as Marx tells us, this has led to the subordination of the industrial sector over the primary.

In another passage, Marx offers a long paragraph where he argues that capital is not only confronted with labor, but with anything that interrupts or hinders its development:

And every process of capitalist agriculture is not only a process in the art of depleting the worker but at the same time in the art of depleting the soil; any advance in the increase of its fertility during a given period, an advance in the depletion of the lasting sources of that fertility[48]. This destruction process is all the faster, the more a country takes big industry as the starting point and foundation of its development. Capitalist production, therefore, does not develop the technique and the combination of the social production process but undermines, at the same time, the two sources of all wealth: land and labor, [in addition to] the need to socially control a natural force, to economize it, to appropriate it or to dominate it on a large scale through the works of the human hand, which plays the most decisive role in the history of industry [49]. 
For Marx, capitalism has developed through the more efficient production and appropriation of surplus-value, which has required the increasing use of more remote lands and previously unexploited resources. In this context, the environment played a role independent of the exploitation of labor power. Still, it is impossible to conceive of a natural limit (in the sense of material resources of the environment) to the development of the productive forces of society. "The barriers that existed to the full realization of the potential of the resources would have been imposed by property relations and legal obligations, and not by the endowment of the resources" [50]. In this regard, there is no contradiction between the dominion that man exercises over nature, so "(...) from a historical materialist perspective, it was a society that placed restrictions on human potential" [12].

So far, we have seen some elements raised by Marx. But now, our concern is to trace Engels's contributions to the study of the economic system, taking into account nature. Following period research, an integral document is identified in social science and is more complete when considering the so-called natural sciences. Research states that since the beginning of human development, it has shaped nature, but only by understanding natural laws can one react to what has caused it. This important document is an integral part of "The role of work in transforming the monkey into a man," in its author argues that economic growth does not have to damage the harmony between man and the environment[33]. The latter brings about a growing "consciousness" of man creating greater responsibilities towards nature.

For Marx, in the specifically capitalist mode of production, nature cannot be seen as something completely external to human reproduction, and therefore to society. The labor theory of value formed by the amount of socially necessary labor leads to the treatment of an ontological and epistemological category [31] of the notion of nature as the objective basis of the material processes of social reproduction. It is a transhistorical category that allows us to understand the complexity of the social totality. For Alfred Schmidt, Nature is the only object of knowledge. It includes both the forms of human society and, inversely, it only appears mentally and really under those forms [37]. However, "(...) he is wrong to consider nature as the terrain of use-values and to forget that what concerns Marx is social use-values, or, in this case, the production of use-values in the form of a 'produced nature' "[51]. That is to say, those natural potentialities that man takes to transform and uses with them. Because it takes a commodity in capitalism, it has to be conceived in terms of the relationship between use value, exchange value, and value.

An extremely important element to add is the study of land rent, which Marx leaves unfinished in his drafts that constitute what we now know as the third volume of capital, published by Engels in 1894. Although not we comment on the differential, extensive and intensive rent and absolute rent, yes, concern Marx's importance to modern land ownership[52]. The study of the rent of the land is oriented to investigate the ownership of the land to the extent that a part of the surplus value generated by the labor force belongs to the landlord, the owner of the land. There are two main characteristics of land rent: its possession and ownership. With these, the conditions of production and the advantageous situation of the landlord in terms of capitalist production are identified. "The possession of the land appears as one of the conditions of production for the direct producer, and his ownership of the land as the most advantageous condition, as a condition for the flourishing of his mode of production" [53]. However, land ownership is distinguished from other types of private property because, from the perspective of the specifically capitalist mode of production, it is unnecessary and harmful due to its basis at a time of development.

With the set of elements raised, we have enough for a methodological and analytical framework that brings us closer to a critique of political economy from the perspective of natural resources. In the first place, if it is known that political economy recognizes the historical specificity of the processes of social formation, the element of environmentalists must be included. And secondly, it is possible to take a set of passages given by Marx and 
Engels that guide us in the construction of an explanatory but systematic apparatus of the man-nature relationship, taking as a tool, for example, the theory of rent, the return on capital, the labor process[54].

\section{The objective theory of value: labor and nature}

The labor theory of value is the master key of the criticism of Marxist political economy since it explains the process of creating new value that is not paid to its producer, the worker. However, when it comes to value, nature falls outside of what Marx takes as economic aspects, even though he has recognized that, as Petty did decades before: “(...) the father of all wealth it is work, and nature is the mother " [55]. In this sense, within the framework of ecological economics, but from a critical perspective such as the criticism of Marxist political economy, it is necessary to introduce the nature variable in analyzing the global reproduction process. In the first part of his book Essay on the nature of commerce in general, Cantillon (1950) suggests that both the price and the intrinsic value of anything are determined by the land and labor involved in its production. Specifically, it states that "(...) the price or intrinsic value of a thing is the measure of the amount of land and work involved in its production, taking into account the fertility or product of the land, and the quality of the work "[56].

In this way, in preclassical thought, we already have nature conceived as a central element in the production of wealth. For this author, the objective theory of value is determined by land and labor, so that it is a theory of land-labor value. This conception has nature and works as a determining unit of the substance of value:

[...] the intrinsic value will be proportionate to the land and labor, but the price will not always follow this proportion [...] The land is matter and work in the form of all products and merchandise, and since those who work it necessarily have to subsist on the product of the land, it seems that a relationship could be found between the value of work and that of the product of the land [...] [57].

After the first half of the 18th century, we find an incipient economic thought in identifying space and matter in creating wealth, which implies the creation of value. Through its main representative François Quesnay, the Physiocracy school postulates that the generation of wealth and value is carried out in the primary activity: agriculture. The merit of this school, especially its contribution to economic thought, is to identify society as asymmetric, divided into social classes, and therefore identify one as productive. Of course, the rest of society is sterile in this scheme.

That said, another advance of the Physiocracy school in analyzing the economic system is to conceive it as a global organic unit where it is produced, distributed, and consumed. The zig-zag scheme proposed by Quesnay represents the set of economic flows in society. On the one hand, we have the real flows, represented by the transit of raw materials from agriculture to manufacturing, food to the rest of society, and articles from this sector to all social classes. The backflow is represented simply as the monetary payment for the purchase of merchandise. As we know, there are two great theoretical-methodological advances of preclassical thought in the field of ecological economics[58]. The first concerns the identification of nature as a generator of value and, therefore, wealth; the second is the identification of a social sector as productive (another as sterile) in the generation of wealth, as well as social reproduction. However, in both cases, nature plays a minor role[59].

From the seventies of the eighteenth century to the entire first half of the nineteenth, classical economists developed a set of theoretical-methodological ideas never before seen in the history of human civilization. The most influential thinkers are Adam Smith and David Ricardo, who in their respective propose an objective theory of value based on human labor. For Smith, the value of a commodity is represented by the amount of labor necessary for its production, but he also accepts the idea of commanded labor, that is, the 
ability of a commodity to acquire others. On his side, Ricardo expresses that utility is essential for work, although it is not his standard of measurement, since things, because they have utility, get their exchange value and because of the amount of work required to manufacture them. But there are goods with a value determined exclusively by their scarcity since labor cannot vary their available quantity. To this extent: "In the initial stages of society, the exchange value of goods, (...), depends almost exclusively on the comparative amount of workers employed in each one" [60].

Following the classical approach, the value of goods results from the amount of work necessary for their production. Marx says that the value of all merchandise is determined by the amount of abstract labor socially necessary for its production, taking into account the normal conditions of production in society, and with an average degree of skill and intensity of work, within the framework of a certain level of scientific development and its technological application[61]. Once the goods are produced, they are exchanged for their monetary equivalent as a producer, in such a way that he obtains the same amount of work materialized in the merchandise, but in money. However, this exchange of equivalents is not always carried out since productive units will appropriate a greater quantity of surplus value concerning the quantity produced. This phenomenon results from the individual conditions of production possessed by capitalists, that is to say, of their organic composition of capital concerning its average. While this discussion is important, it is not the nerve center discussing the value-generating substance[62].

Taking as a reference Marx's objective theory of labor value as that of greater refinement concerning that of the classical economists, let us reflect on and with it in terms of an objective theory of value that incorporates both human labor and the aspect of resources. Beforehand, let us remember that we intend a new objective theory of value from afar, nor do we intend to redo Marx's proposals. As proposed by Alvater, our reflection points to an ecological critique of political economy within the theory of value. In other words, taking the capitalist mode of production as the stage, not only at present but throughout its existence, the exploitation of labor power and nature has been reported. To develop this, the capitalist has availed himself of the increasing appropriation of the means of production and thus has led the proletariat to sell its physiological capacities[6370]. Historically, what has been determined is a social relationship of production characterized by wage labor, but what is the relationship between capital and nature? It is clear that with the exploitation of labor power, capital appropriates value that does not correspond to it since it is not the result of work; In the case of nature, how is it that capital obtains wealth if it is not the result of work?

For nature to be conceived as a creative source of value, we have to structure an objective theory of value. One of the possibilities is that this theory could propose incorporated energy as the direct source and substance of value. This approach would be consistent with the first law of thermodynamics, the law of conservation of energy. The proposal consists of the following. Costanza states that by assuming that prices reflect production costs, they see incorporated energy as the source and substance of economic value. "A theory of the value of incorporated energy postulates that a perfect functioning of the market, through a complex process of evolutionary selection, would arrive at prices proportional to the intensity of incorporated energy" [71]. Embodied energy better explains the total and relative costs of goods for energy value theorists based on this approach.

For this reason, Daly responds that this approach presupposes the absence of monopolistic imperfections in the markets for raw materials and finished goods, and in all those markets for sources and types of energy used in production, including solar energy, is fundamental in eco-systemic reproduction [69]. Even more worrying is the search for the quantitative Holy Grail of a simple primary input, where the energy approach presupposes that all-natural resources can be reduced to a homogeneous unit in pure energy terms. Therefore, the energy approach would be nothing more than a reductionist procedure of the value of inputs and products, which leaves aside social relations. 
The energy theory of value approach has a severe lack of criticism of reductionism and the role of the market. The reductionism to amounts of energy of the use-values of nature as production inputs presents two assumptions in material and entropic terms. The first refers to the energy incorporated, directly and indirectly, required in the production of material structures[11]; the second suggests that this energy incorporated in material structures is taken as a measure of the degree of organization, but considering the low level of entropy it contains. If these two points clarify something, the search for a primary input on the energy theory of value is driven by its reductionism of the value question, independently of the historical specificity of the relations of production. But this approach is a small step to see that money and markets are just right for registering these exchange values as energy values. The uncritical stance of the theoretical approach to energy on the commercialization of nature is also reflected in its different inexplicable appeal to the neoclassical theory of utility with its correspondence between market prices and subjective valuations of nature[53].

To have a better analytical scheme of economic value under capitalism, we do not need this economic system to be fully accounted for in terms of nature. It is important to remember that capital exploits all the elements at its disposal within the capitalist valorization process, including natural resources. In this way, based on Figure 4, let us illustrate the determination of integral value, which conceives work and nature as direct determinants of wealth. On the one hand, we have the mercantile value determined by the amount of human labor, with which Marx derives a set of categories, among which is the surplus value as the amount of value (work) not remunerated to the worker. From this angle, the value represents a social relationship between the capitalist and the worker; It is a relationship of subordination where the owner of the means of production decides the form and proportions of the distribution of the result of work(see Figure 4)[58].

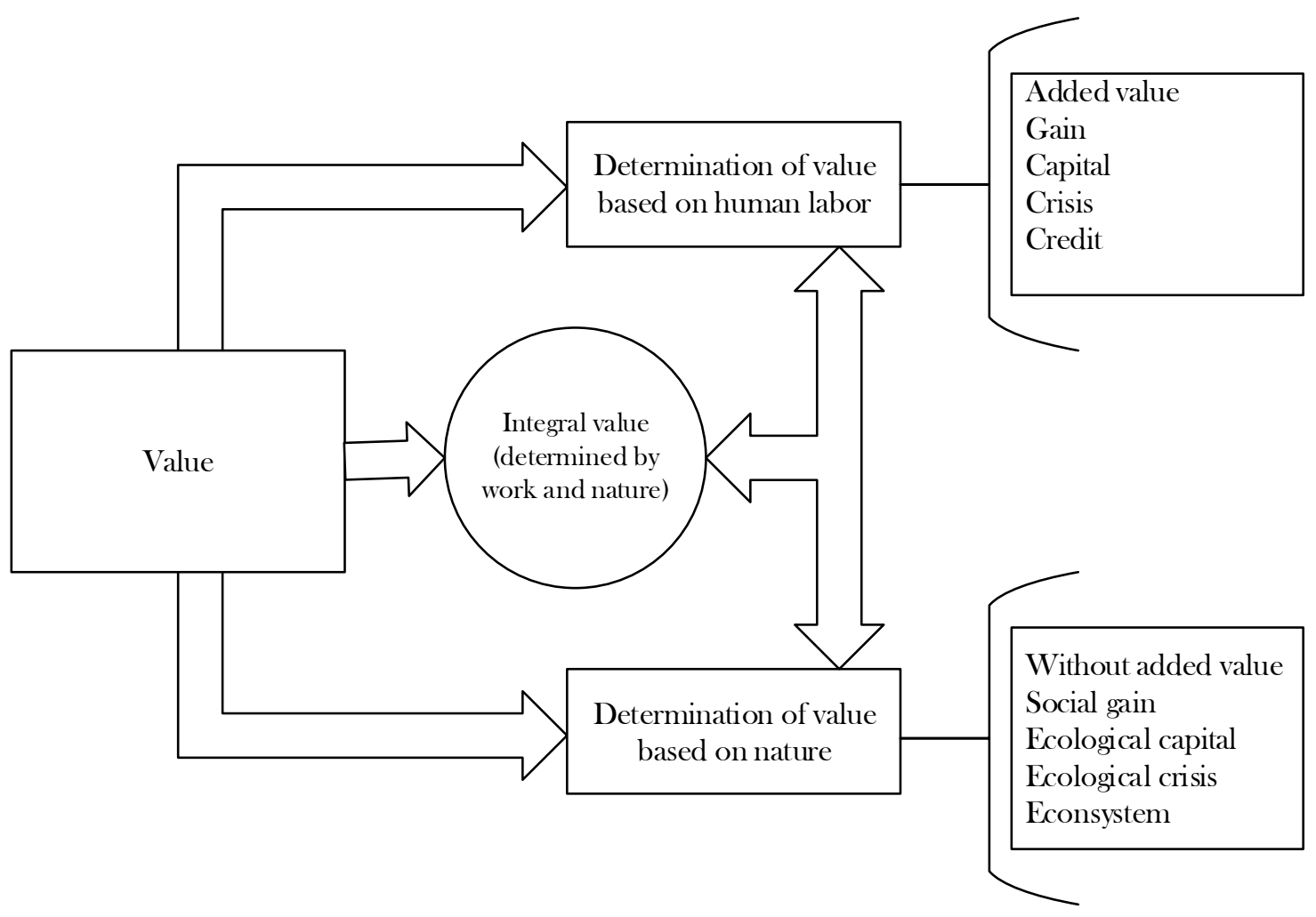

Figure 4. Determination of the mercantile value

The eco-Marxist approach does not develop the mediation of the appropriation of the natural conditions of capital through the social separation of workers from the system of 
conditions and the alienated form of their unification as an employment relationship [23]. The result obtained in this approach is the attempt to attribute value directly to nature, which is within the contradictions of the capitalist system when it tries to explain how said value appears once it has been extracted. To understand the specific forms of use and valuation of nature in capitalism, we do not need a theory of value concerning other historical forms. The construction of an integral theory of value requires considering one of the liveliest debates in ecological economics. This refers to the second law of thermodynamics, the law of entropy, and with it, we have to develop an approach that relates economics and entropy. According to Burkett, a Marxist analysis of the nexus between economy and entropy begins with the specification of production's social and material relations [44].

Indeed, in transhistorical teres, a theory of value is not required to study the exploitation of natural resources. Still, the analysis of the appropriation and result of work in the capitalist mode of production does not need an objective theory of energy value. This is because, between nature and capital, there is no relationship of the kind that exists between labor and capital. Even more, studying contemporary capitalism based on the laws of thermodynamics is adequate; however, reducing nature to an energy value is a later moment than what has to be studied: the process of expropriation of man's natural resources by man[17]. It is true that if a fraction of society has been deprived of its natural resources for survival, it will only have its physiological capacities for itself, which will come to the thief. At an advanced stage, this capitalist process experiences periodic economic crises rooted in the stresses of capitalist accumulation and natural conditions, including human and environmental conditions. Still, considering the entropic ecological dynamics of capitalism, these crises are endless and can only be overcome by the communalization of production and its material conditions employing producers and their communities [19].

\section{Political economy: a green-red perspective}

Having an analytical approach that allows critically studying the historical process of exploiting natural resources leads us to consider capitalism's first and second contradictions. The first consists of the struggle between labor and capital, that is to say, the historical class struggle for the distribution of the result of work[17]. This contradiction is expressed in an economic-sociological category, the rate of exploitation, which expresses the relationship of economic, political, and social power that the capital exercises overwork. Likewise, this category, together with the rate of return of capital, presents an inherent tendency to the crisis on the part of capitalism that can be different and realization, of overproduction, underconsumption, disproportionality. Still, above all, it is a crisis of over-accumulation. The process of capitalist reproduction, which, as Marx had said, is dynamic, develops the productive forces, constantly the same amount of capital requires a lesser amount of living labor for its valorization[18]. "The first contradiction of capitalism is internal to the system; it has nothing to do with the conditions of production, whether they are interpreted economically or in socio-political terms "[17]. As this first contradiction is fully defined in terms of value, the capitalist economic system demands a greater quantity of other people's labor, but with the other, what it does is repel it by increasing the dead labor in the production process - a place where value and wealth are created.

The second is the requirement for more complex terminology in terms of use-value. Unlike the first, this second contradiction does not identify any variable as the most prevalent or with which the interruption of the development of the capitalist economic system is identified[21]; not all the analysis variables have comparable theoretical importance. This contradiction consists of the fact that the development of the capitalist economic system erodes, and up to a certain point, destroys the general production conditions. In this 
scenario, the capitalist valuation process is hit by the cost of production, since when witnessing an "externality," some capitalists will raise their costs in defense of their benefits, causing the collective capitalist to be disadvantaged in their valuation. In other words, the second contradiction of capitalism lies in the fact that the ecosystem places natural and unbreakable limits on the capitalist reproduction process; the spur of capitalism, the rate of profit, leads us to consider as merchandise everything that is not produced by labor. In other words, the destructive and predatory capitalism of natural resources assigns a price to what has no value, but what it sells is nothing but the material base on which it stands, on nature[23].

We cannot argue that of the two contradictions of capitalism, the first is endogenous and the second exogenous to its operation, since both are inherent in the development of capitalism, in addition to being inherent to the development of capitalism, only that in one capital is confronted with work, while in the other is based on available natural resources. Figure 5 illustrates the two types of economic crises from a Marxist perspective. The first type is the result of overproduction due to the realization crisis; the second is the crisis of underproduction due to the destruction of the general production conditions. Having reviewed capitalism's first and second contradictions as the basis of the green and red approach to political economy, let us comment on their characterization[24].

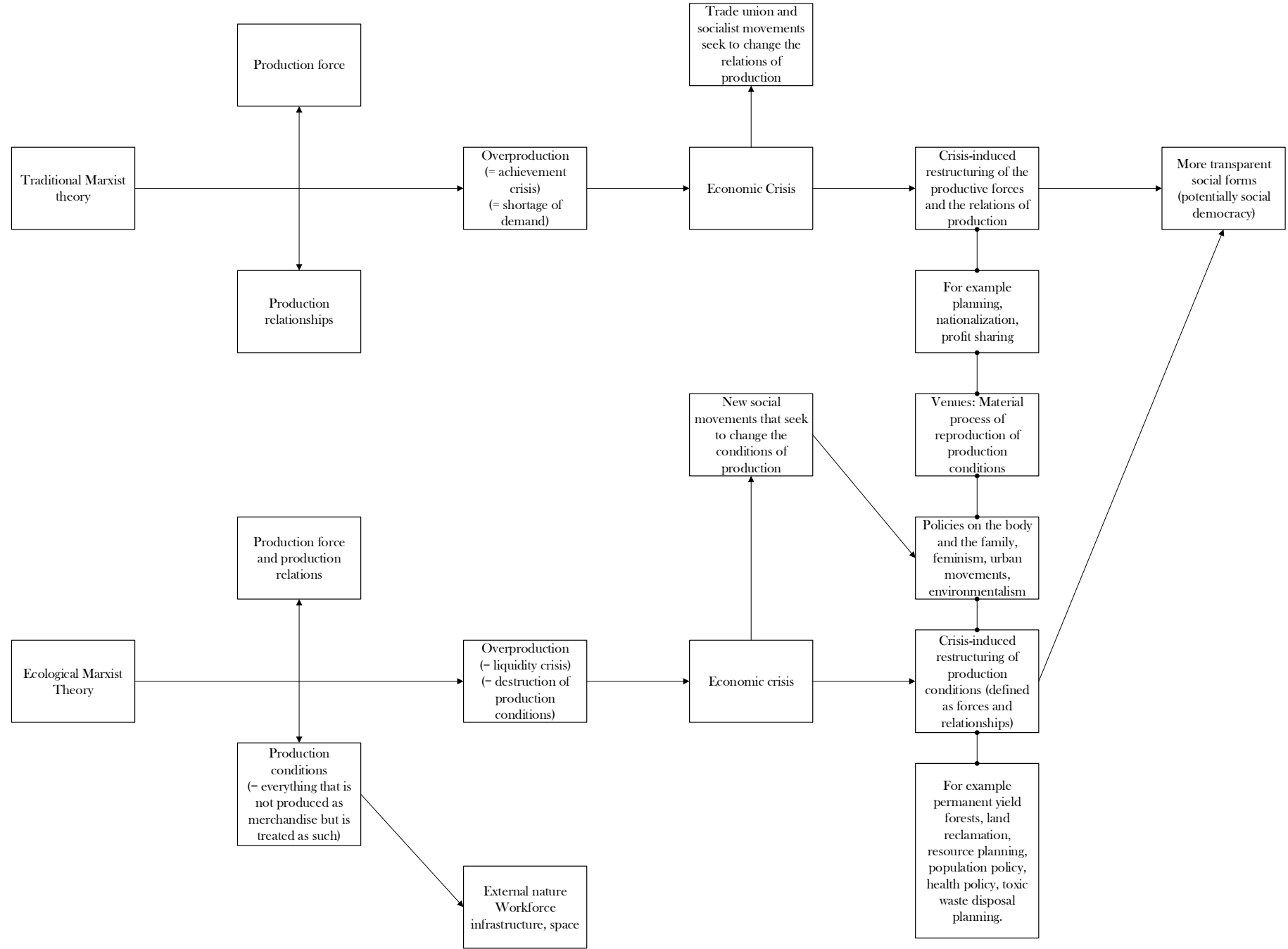

Figure 5. The first and second contradiction of capitalism 
Taking O'Connor's arguments as a point of reference, it is ironic that today many people conceive that with the fall of the socialist bloc, a little over a decade ago (1989 with the fall of the Berlin Wall and in 1991 with the dissolution of the socialist bloc commanded by the former USSR), the analysis developed and proposed by Marx is dead[27]. On the threshold of the 21st century, today, one hundred and forty years after the first edition of capital, the dominant theoretical current imposed by neoliberalism has insisted on disdaining any social scientific study that has a heterodox analysis as its starting point, especially if it is Marxist Political Economy. At the beginning of the century mentioned above, the prospects for green-red political movements in the central countries are not encouraging since the growing economic and ecological crises since the eighties have led to the reconstruction of structures of global domination by capital. The ways of conducting economic policies have been substantially modified in favor of methods of overexploitation of the labor force and natural resources[39].

The transformation has not led to new vehicles of social assistance, nor has it led to a profound reform of social and political institutions, much less a revolutionary change in favor of society. We have an overwhelming neoliberal global state that excludes broad segments of society from the distribution of wealth and polarization and subordination not of countries but entire regions. It is a state that seeks to favor capitalist profitability at all costs, preferably non-productive ones. Faced with this situation, society generates antisystemic movements capable of resisting capital's onslaught but responding to them through alternative forms of social organization. One of them is the social movements of the green and red types [47].

A red-green political movement has two basic assumptions. One is an understanding of the current contradictions in the world economy, especially the changing position of the United States in global capitalism, and thus the scope and possible limits of radical green politics. The second is a reflective understanding of the parts and potentialities that constitute the movement [67].

The result of this is that the greens have been adopting a redder discourse, and the reds have incorporated elements of the green discourse into theirs.

The formation of the green and red movement has many challenges, and with reservations, it is asked if it is possible to organize it. This challenge is huge in the international arena, but the answer would lead us to establish new ways of life: democratically, with ecological and economic rationality, and socially equitable. The challenges are diverse, and such is the case of linking economic, social, political, cultural problems, etc., in a theoretical and practical sphere, in such a way that they facilitate alternative development paths for the future of society. As a highly alienated, individualized, and alienated society, we must overcome the division of opinion to conquer capital's power. We have to overcome the differences of the different antisystemic social classes since, with social synergy, we do not seek a consensus with the current hegemony but rather discard its old structures to preserve power. For this, we require green and red approach to thinking and political work[51].

The title of one of Burkett's books poses Marxism and ecological economics as a single body of analysis, where he calls for a red and green Political Economy. He provides us with a broad development of a set of economic issues of capital importance related to ecological economics, but within the framework of the work developed by Marx. We find from the problem of value, natural capital, and the law of entropy to sustainable human development and the Marxist approach to ecological conflicts and crises. However, as Alvater discusses[70, 71]:

[...] Is there a rational need for this type of color composition between ecological economy and political economy? It would seem that a contemporary economic analysis assumes that red is the critical aspect, while green is the incorporation of natural resources into the analysis. However, given the development of social democracy and green parties 
and movements, as well as the recognition of both theoretical efforts and 'progress' towards a red and green political economy, they are disappointing, at least in Europe, then What justification can we give for such a theoretical-political position?

If so, you have to give answers on direct the theoretical discussion and the daily practice.

What is happening with the contributions to political economy by the Greens is that they are practically non-existent, or worse still, since they are based on postmodern liberal or neoliberal approaches. By far, we are faced with a critical stance from organizations and institutions that claim to protect the ecosystem. And it is not surprising that political parties like the greens in Germany, or the environmentalist green in Mexico, in the words of Alvater, are tending to the colors of the Jamaican flag: yellow, black, and green. These parties generate the gear for a political coalition with the neoliberals (yellow) and the conservatives (black). These green organizations do nothing but reject the class perspective, not only them, since a wide swath of the world left is characterized by a strong critical political disorientation, the more so of the care and preservation of natural resources. Furthermore, contemporary movements, both red and green, identify less and less with the ideals of communism and thus are constantly less supportive[71].

Generating an efficient green and red movement requires that both the greens and the reds not only think globally and act locally, but also think locally and act globally.

For Greens, "think globally, act locally" means (among other things) "think about the effects of what you are doing on the global environment" [...] "think globally, act locally" must also take into account the reality that certain localities define themselves, or acquire self-definitions, both cultural and environmental, in such a way that they are also constituted by world capitalism [33].

Having a red-green perspective is a process of self-management social organization, preserving the harmony of human development and ecosystem development.

The result of this is that the greens have been adopting a redder discourse, and the reds have incorporated elements of the green discourse into theirs.

The formation of the green and red movement has many challenges, and with reservations, it is asked if it is possible to organize it. This challenge is huge in the international arena, but the answer would lead us to establish new ways of life: democratically, with ecological and economic rationality, and socially equitable. The challenges are diverse, and such is the case of linking economic, social, political, cultural problems, etc., in a theoretical and practical sphere, in such a way that they facilitate alternative development paths for the future of society. As a highly alienated, individualized, and alienated society, we must overcome the division of opinion to conquer capital's power. We have to overcome the differences of the different anti-systemic social classes since, with social synergy, we do not seek a consensus with the current hegemony but rather discard its old structures to preserve power. For this, we require green and red approach to thinking and political work[37].

The title of one of Burkett's books poses Marxism and ecological economics as a single body of analysis, where he calls for a red and green Political Economy. He provides us with a broad development of a set of economic issues of capital importance related to ecological economics, but within the framework of the work developed by Marx. From the value problem, natural capital, and the law of entropy to sustainable human development and the Marxist approach to ecological conflicts and crises. However, as Alvater discusses[39]:

[...] Is there a rational need for this type of color composition between ecological economy and political economy? It would seem that a contemporary economic analysis assumes that red is the critical aspect, while green is the incorporation of natural resources into the analysis. However, given the development of social democracy and green parties 
and movements, as well as the recognition of both theoretical efforts and 'progress' towards a red and green political economy, they are disappointing, at least in Europe, then What justification can we give for such a theoretical-political position?

If so, you have to answer how to direct the theoretical discussion and the daily practice[69].

What is happening with the contributions to political economy by the Greens is that they are practically non-existent, or worse still, since they are based on postmodern liberal or neoliberal approaches. By far, we are faced with a critical stance from organizations and institutions that claim to protect the ecosystem. And it is not surprising that political parties like the greens in Germany, or the environmentalist green in Mexico, in the words of Alvater, are tending to the colors of the Jamaican flag: yellow, black, and green. These parties generate the gear for a political coalition with the neoliberals (yellow) and the conservatives (black). These green organizations do nothing but reject the class perspective, not only them, since a wide swath of the world left is characterized by a strong critical political disorientation, the more so of the care and preservation of natural resources. Furthermore, contemporary movements, both red and green, identify less and less with the ideals of communism and thus are constantly less supportive[70].

Generating an efficient green and red movement requires that both the greens and the reds not only think globally and act locally but also think locally and act globally.

For Greens, "think globally, act locally" means (among other things) "think about the effects of what you are doing on the global environment" [...] "think globally, act locally" must also take into account the reality that certain localities define themselves, or acquire self-definitions, both cultural and environmental, in such a way that they are also constituted by world capitalism [11].

Having a red-green perspective is a process of self-management social organization, preserving the harmony of human development and ecosystem development.

\section{Conclusion}

The elements on which the study method of social phenomena places greater emphasis depending on the historical moment of the development of human civilization. At present, the path that the process of social reproduction on a planetary scale will follow is uncertain since the overexploitation of natural resources and their consequent depletion have taken an important role in the theoretical, methodological, and empirical study of the social sciences and government policies. Methodologically, it is no longer possible to exclude natural resources in studying the behavior and direction of contemporary capitalism.

In this document, four fundamentals of the political, ecological economy have been synthetically presented. First, mention the emptiness of conventional forms in the study of economics by incorporating thermodynamic flow in the production and distribution process. Second, Marx and Engels's main contributions in the incorporation of nature within the capitalist reproduction process. The transhistorical process of production and the role of labor in the development of society, and the theory of land rent as a tool for analyzing the competition. Third, the objective theory of value is determined exclusively by work, energy (following the laws of thermodynamics), or an integral vision. And fourth, the green-red vision of political economy emphasizes the search for alternative forms of social organization, where man lives in harmony with nature. The green movements will have to assume a critical position, while the red ones will incorporate the nature variable in their analysis.

The history of human thought has characterized man in different ways, according to his profile. According to the political essence of it: zoon political. Attending the reproduction and distribution processes: human economics. Currently, commanded by capitalist valorization and the destruction of the ecosystem: homus devastus. 


\begin{abstract}
Author Contributions: "Conceptualization, NN. and EA.; methodology, NN.; software, EA.; validation, NN. and EA.; formal analysis, NN.; investigation, EA.; resources, NN.; data curation, EA.; writing - original draft preparation, NN.; writing - review and editing, EA.; visualization, NN.; supervision, NN.; project administration, EA. All authors have read and agreed to the published version of the manuscript."
\end{abstract}

Funding: "This research received no external funding."

Conflicts of Interest: "The authors declare no conflict of interest."

\title{
References
}

[1] Gale, F.P. The Political Economy of Sustainability; Edward Elgar Publishers: Northampton, MA, USA, 2018.

[2] Endres, A. Environmental Economics Theory and Policy; Cambridge University Press: New York, NJ, USA, 2011.

[3] World Commission on Environment and Development. Our Common Future; Oxford University Press: New York, NJ, USA, 1987.

[4] Gallie, W. Essentially contested concept. Proc. Aristot. Soc. 1955, 56, 167-198.

[5] Smith, A. The Wealth of Nations: Books I-III; repr. 1986; Penguin: London, UK, 1776.

[6] List, F. National System of Political Economy; repr. 1856; J.B. Lippincott \& Co.: Philadelphia, PA, USA, 1841.

[7] Meadows, D.H.; Meadows, D.L.; Randers, J.; Behrens, W.W., III. The Limits to Growth; A Report for the Club of Rome's Project on the Predicament of Mankind; Universe Books: New York, NJ, USA, 1972.

[8] Daly, H. Steady-State Economics: The Economics of Biophysical Equilibrium and Moral Growth; W.H. Freeman: San Francisco, CA, USA, 1977.

[9] Dobson, A. Environment sustainabilities: An analysis and a typology. Environ. Politics 1996, 5, 401-428.

[10] Solow, R.M. Intergenerational equity and exhaustible resources. Rev. Econ. Stud. 1974, 41, $29-46$.

[11] Jacobs, M. Sustainable development as a contested concept. In Fairness and Futurity: Essays on Environmental Sustainability and Social Justice; Dobson, A., Ed.; Oxford University Press: Oxford, UK, 1999; pp. 22-45.

[12] Hopwood, B.; Mellor, M.; O’Brien, G. Sustainable Development: Mapping Different Approaches. Sustain. Dev. 2005, 13, 3852.

[13] Connelly, S. Mapping sustainable development as a contested concept. Local Environ. 2007, 12, $259-278$.

[14] Robins, L. An Essay on the Nature and Significance of Economic Science; Macmillan: London, UK, 1932.

[15] Munda, G. "Measuring sustainability": A multi-criterion framework. Environ. Dev. Sustain. 2005, 7, 117-134.

[16] Arnstein, S. A ladder of citizen participation. J. Am. Inst. Plan. 1969, 35, 216-224.

[17] Kahneman, D. Thinking, Fast and Slow; Macmillan: New York, NJ, USA, 2011.

[18] Fricker, A. Measuring up to Sustainability. Futures 1998, 30, 367-375.

[19] Sabau, G. Costa Rica: A Champion of the Small-Scale Fisheries Guidelines, chapter in S. The Small-Scale Fisheries Guidelines; Springer: Cham, Switzerland, 2017; pp. 355-378.

[20] The Sustainable Development Paradox: Urban Political Economy in the United States and Europe; Krueger, R.; Gibbs, D. (Eds.) Guilford Press: New York, NY, USA, 2007.

[21] Harris, J.M. Environmental and Natural Resource Economics: A Contemporary Approach, 2nd ed.; Houghton Mifflin: Boston, MA, USA, 2006; pp. 33, 472-473.

[22] Lélé, S. Sustainable development: A critical review. World Develop. 1991, 19, 607-621.

[23] Daly, H. Beyond Growth: The Economics of Sustainable Development; Beacon: Boston, MA, USA, 1996.

[24] Bromley, D. Environmental regulations and the problem of sustainability: Moving beyond "market failure". Ecol. Econ. 2007, 63, 676-683.

[25] Jackson, T. Prosperity without Growth; Earthscan: London, UK, 2009.

[26] Redclift, M. Sustainable Development: Exploring the Contradictions; Methuen: London, UK, 1987.

[27] Rees, W.E. The ecology of sustainable development. Ecologist 1990, 20, 18-23.

[28] Foster, J.B. Ecology and human freedom. Mon. Rev. 1995, 47, 22-31.

[29] Castro, C. Sustainable development: Mainstream and critical perspectives. Organ. Environ. 2004, 17, $195-225$.

[30] Just Sustainabilities: Development in an Unequal World; Agyeman, J.; Bullard, R.; Evans, B. (Eds.) MIT Press: Cambridge, MA, USA, 2003.

[31] Robbins, L. An Essay on the Nature and Significance of Economic Science; Macmillan: London, UK, 1952.

[32] Heilbroner, R.; Milberg, W. The Making of Economic Society; Prendice Hall: New York, NY, USA, 2006.

[33] Liodakis, G. Totalitarian Capitalism and Beyond; Ashgate Publishing: Surrey, UK, 2010.

[34] Perelman, M. Myths of the market: Economics and the environment. Organ. Environ. 2003, 16, 168-226.

[35] Swaney, J. Common property, reciprocity, and community. J. Econ. Issue. 1990, 24, 451-462.

[36] Bollier, D. Silent Theft: The Private Plunder of Our Common Wealth; Routledge: London, UK, 2003.

[37] Burkett, P. Marxism and Ecological Economics: Toward a Red and Green Political Economy; Brill Academic Publishers: Boston, MA, USA, 2006. 
[38] Marx, K. Capital I; International Publishers: New York, NY, USA, 1967; pp. 507, 509, 737, 762.

[39] Harvey, D. The New Imperialism; Oxford University Press: Oxford, UK, 2003.

[40] Liodakis, G. The people-nature relation and the historical significance of the labour theory of value. Capital Class 2001, 73, $113-140$.

[41] Foster, J.B. Marx's Ecology: Materialism and Nature; Monthly Review Press: New York, NY, USA, 2000; pp. 152-154.

[42] Burkett, P. Marx and Nature: A Red and Green Perspective; Macmillan: London, UK, 1999; pp. 68-78, $194-197$.

[43] Lodziak, C. Manipulating Needs: Capitalism and Culture; Pluto Press: London, UK, 1995.

[44] Smith, A. An Inquiry into the Nature and Causes of the Wealth of Nations; Clarendon Press: Oxford, UK, 1976 ; p. 155.

[45] Marx, K. Grundrisse; Vintage Books: New York, NY, USA, 1973; pp. 83-108.

[46] Clark, B.; York, R. Rifts and shifts: Getting to the root of environmental crises. Mon. Rev. 2008, 60, 13-24.

[47] Marx, K. Capital III; International Publishers: New York, NY, USA, 1967; pp. 745, 776, 812, 820.

[48] O'Connor, J. Natural Causes: Essays in Ecological Marxism; Guilford Press: New York, NY, USA, 1998.

[49] Allen, R.C. The efficiency and distributional implications of 18th century enclosures. Econ. J. 1982, 92, 937-953.

[50] Runge, C.F. Common property and collective action in economic development. World Develop. 1986, 14, $623-635$.

[51] O'Neill, J. Property, care, and environment. Environ. Plan. C-Gov. Policy 2001, 19, 695-711.

[52] Ostrom, E. Collective action and the evolution of social norms. J. Econ Perspect. 2000, 14, 137-158.

[53] O’Neill, J. Markets, Deliberation and Environment; Routledge: London, UK, 2007.

[54] Liodakis, G. The role of biotechnology in the agro-food system and the socialist horizon. Hist. Mat. 2003, 11, 37-74.

[55] Smith, N. Uneven Development: Nature, Capital and the Production of Space; Blackwell: Oxford, UK, 1984.

[56] Castree, N. The nature of produced nature: Materiality and knowledge construction in Marxism. Antipode 1995, $27,12-48$.

[57] Dickens, P. Reconstructing Nature: Alienation, Emancipation and the Division of Labour; Routledge: London, UK, 1996.

[58] Swyngedouw, E. Impossible "Sustainability" and the Political Condition; Krueger, R., Gibbs, D., Eds.; Guilford Press: New York, NY, USA, 2007.

[59] Wallis, V. Capitalist and socialist responses to the ecological crisis. Mon. Rev. 2008, 60, 25-40.

[60] Burkett, P. Entropy in ecological economics: A marxist intervention. Hist. Mat. 2005, 13, 117-152.

[61] Smith, R. Beyond growth or beyond capitalism? Real-world Econ. Rev. 2010, 53, 28-42.

[62] O'Connor, M. Is Capitalism Sustainable? The Guilford Press: London, UK, 1994.

[63] Singer, M. Economics: Are the planet-unfriendly features of capitalism barriers to sustainability? Sustainability 2010, 2, 127144.

[64] Trainer, T. The "de-materialisation" myth. Technol. Soc. 2001, 23, 505-514.

[65] Næss, P.; Høyer, G. The emperor's green clothes: Growth, decoupling, and capitalism. Capital. Nat. Social. 2009, $20,74-95$.

[66] Sheasby, W. Inverted world: Karl marx on enstrangement of nature and society. Capital. Nat. Social. 1997, 8, 31-47.

[67] Market Socialism: The Debate among Socialists; Ollman, B. (Ed.) Routledge: New York, NY, USA, 1998.

[68] McNally, D. Against the Market: Political Economy, Market Socialism and the Marxist Critique; Verso: London, UK, 1993; pp. 190-193, 206, 212.

[69] Shiva, V. Earth Democracy. In New Socialisms: Futures Beyond Globalization; Albritton, R., Bell, S., Westra, R., Eds.; Routledge: London, UK, 2004; pp. 53-70.

[70] Boudjelida, A.; Mellouli, S.; Lee, J. Electronic citizens participation: Systematic review. In Proceedings of the 9th International Conference on Theory and Practice of Electronic Governance, Montevideo, Uruguay, 1-3 March 2016; Association for Computing Machinery: New York, NY, USA, 2016; Volume 1, pp. 31-39.

[71] Killian, S.; Lannon, J.; Murray, L.; Avram, G.; Giralt, M.; O’Riordan, S. Social Media for Social Good: Student engagement for the SDGs. Int. J. Manag. Educ. 2019, 17, 100307. 